\title{
THE RECONSTRUCTION OF NATO IN THE POST TRUMP ERA
}

\section{Ige Kehinde Moses}

Department of Public Administration, Faculty of Political Science and Economics, 200 Prospect St, East Stroudsburg, East Stroudsburg University, PA 18301, United States

Email: amazingkheni@gmail.com

\section{Cite this article:}

Ige Kehinde Moses (2021), The Reconstruction of NATO in the Post Trump Era. Journal of Advanced Research and Multidisciplinary Studies 1(2), 10-17. DOI: 10.52589/JARMSRNNHSJE6.

\section{Manuscript History}

Received: 23 Oct 2021

Accepted: 9 Nov 2021

Published: 25 Nov 2021

Copyright $\odot 2020$ The Author(s). This is an Open Access article distributed under the terms of Creative Commons AttributionNonCommercial-NoDerivatives 4.0 International (CC BY-NC-ND 4.0), which permits anyone to share, use, reproduce and redistribute in any medium, provided the original author and source are credited.
ABSTRACT: The complexities inherent in the process of reconstruction is one that cannot be overemphasized, most importantly, the need to reconstruct NATO in the post Trump era. The North Atlantic Treaty Organization was established in 1949 with the aim of providing collective security against threats and ideological conflicts posed by the Soviet Union. The United States of America has since then played strategic, pivotal and leadership roles for the sustainability of NATO. The organization's essential purpose is to safeguard the liberty and security of all its members by both political and military endeavors. Collective defense and security heart is the alliance, as well as the need to foster unity, solidarity and cohesion amongst member states. This paper, hinged on historical and analytical approaches, examines the essence of NATO from a historical perspective, and proper solutions as regards the reconstruction of NATO in the post Trump era. Evidently, realities on ground show the need to reconcile alongside member states, the vision and purpose of NATO in the 21st Century.

KEYWORDS: The United States, NATO, Reconstruction, Post Trump era, Soviet Union, Collective defense, Donald Trump, International Organisation. 


\section{INTRODUCTION}

\section{Preamble}

NATO is a quintessential international organization founded and established in the year 1949, which is made up of 30 member states from Europe and North America that exist to protect the people and territory of its members. NATO's vision and mandate is based on universal security and collective defense. Its member states include Albania, Belgium, Bulgaria, Canada, Croatia, Czech Republic Denmark, Estonia, France, Germany, Greece, Hungary, Iceland, Italy, Latvia, Lithuania, Luxembourg, Montenegro, Netherlands, North Macedonia, Norway, Poland, Portugal, Romania, Slovakia, Slovenia, Spain, Turkey, United Kingdom and the United States of America. The unorthodox leadership style of former President Donald Trump brought about distortions and foreign policy changes not only within the United States but also greatly influenced its roles in international organizations such as the United Nations and NATO, as such changes went on to greatly impact the United States' participation in issues such as world peace and climate change, amongst others. While Donald Trump's domestic and foreign policies were centred on America and America alone, his policy of isolation removed the United States from its original vision for the world. His constant emphasis on "America First" re-defined America's domestic and foreign policies which negatively impacted America's global hegemonic status. This paper therefore revisits the discourse on the overhaul and reconstruction of the Septuagenarian North Atlantic Treaty Organization (NATO) in the post Trump era.

The finding was that the effect of former president Trump's political dogma impacted negatively on the North Atlantic Treaty Organization as a whole, as well as the roles of its member states, as there was a need to fill the vacuum and void left by the United States. Under President Trump presently, we see a massive rise in the importance and significance of international organisations in contemporary international relations due to its political, economic and military functions performed in accordance with its prescribed goals and objectives as well as that of its member states. Although twelve countries took part in the founding of NATO (France, Denmark, Canada, Belgium, Iceland, Italy, Luxembourg, the Netherlands, Norway, Portugal, the United Kingdom, and the United States), the Adriatic States of Croatia and Albania joined the 6th enlargement in 2009, Montenegro in 2017 and North Macedonia in 2020. Historically, NATO and the United States have had their own challenges. According to Philip Windsor, "The United States has reaffirmed her commitment to the defence of Europe, but the alliance is still threatened by a growing discrepancy between integration in the central area and disintegration on the periphery" [Windsor, 1975].

Today, we see the importance of regional groupings and regional effects on world politics. Nations have transitioned from a sense of self dependence and reliance to cohesive inter-state relations. Although often limited to geographical terms, regions are political entities not fixed by geography. The reason for the absence of NATO in Asia was based on the realities of the time at the beginning of the Cold War and the difference in mutual identification, in combination with material factors, and consideration of efficiency was of critical importance in defining the interests and shaping the choices of US and Asia; these dynamics were responsible for the lack of NATO in Asia [Hemmer \& Katzenstein, 2002]. 
NATO is a classic example of an alliance. The organization was launched by western countries to ensure the security of its member states, which in practice meant detering the threat posed by the Soviet Union and the states affiliated with it in the Warsaw Pact [Frydrych, 2008].

\section{Conceptual Clarifications}

While there are some principal concepts adopted in this paper, it is essential to establish an indepth meaning to these concepts to further enable clarity on NATO as an international organization, and the need for the proposed reconstruction in the post Trump era.

\section{NATO}

NATO is the most powerful alliance in the world and an integral part of the US national security [Benitez, 2019]. NATO, also known as the North Atlantic Alliance, is an intergovernmental military alliance established on the 4th of April, 1949 with its headquarters in Brussels, Belgium. The organization implements the North Atlantic Treaty that was signed on the 4th of April, 1949.

\section{Reconstruction}

The term reconstruction deals with the idea of building something, rearranging, reorganizing or restructuring, or the process of putting together something that was damaged or destroyed such as a nation or country, an institution, cooperation or organization. The interpretation and definition of the word is peculiar to the field and context to which it is defined.

However, its basic definition is the process of rebuilding due to an error or some form of deformity associated with what is being rebuilt. Within the context of this paper, the term reconstruction pertains to the proposition of rebuilding NATO in the post Trump era.

\section{Soviet Union}

The Soviet Union, officially the union of Soviet Socialist Republics, was the Union of Socialist states that spanned across Europe and Asia. The Soviet Union was founded on the 30th of December, 1922. The primary vision of the union was its intention to transform itself from a nation state into a world state [Goodman, 1953]. While there is no categorical reason for the collapse of the Soviet aside the external forces posed by the West, it is perceived that the notion of a politicized military was a contributing factor responsible for the demise [Meyer, 1991].

\section{Donald Trump}

Donald John Trump is an American media personality, entrepreneur and businessman who served as the 45th president of the United States from the year 2017 to 2021 . He is 75 years old and was born in Jamaica Hospital Medical Center, New York. His unorthodox approach to governance somewhat proved rigid not only to some percentage of Americans but also to political analysts, political commentators, scholars, observers, researchers, and world leaders. According to Douglas Kellner, he described Donald Trump as an authoritarian populist. His assertion on Donald Trump was based on the Frommian Analysis that helps describe Trump's character and temperament as his major flaw that affected his administration and rule as president of the United States [Kellner, 2018]. 
Donald J. Trump's administration was characterized by the violation of international and domestic norms that ultimately affected the United States' relations with both her allies and other nations of the world [Panke \& Petersohn, 2017].

It is safe to say that Donald Trump shook the American political landscape to its foundations [Conley, 2020]. His blatant disregard for public opinion as well as the plight of the average American was a source of fear and discomfort for Americans from all walks of life. His reputation for keeping people guessing made his administration unpredictable. As he stated on Twitter, "I love watching these poor, pathetic people (pundits) on television working so hard and so seriously to try and figure me out" [Conley, 2020]. Cory Wimberley in his article Trump, Propaganda, and the Politics of Ressentiment, framed Trump's politics through a genealogy of propaganda; he asserted Trump's administrative policies further deepened class stratification and disparities in America [Wimberley, 2018].

\section{Collective Security}

The term collective security defines the system by which states attempt to hinder or stop war. This desire is attained through an agreed collective security arrangement that defines the parameters as which states are to function to achieve growth and sustainable peace. Nations hereby pledge to collectively ensure the protection, defense and ultimately the sovereignty of member states. One of the most fundamental characteristics for our troubled times is the universal quest for security in which contemporary mankind is engaged [Rappard, 1946].

Security in itself is multifaceted in nature. It could be political, social, cultural or economic. For example, in 1973, and again at its 57th session in Geneva in July 1974, the United Nations Economic and Social Council debated the question of collective economic security [Nye, 1974]. The establishment of a collective system of security by various states is defined by their collective identity formation. This identity is based on variables such as political ideology, globalization, civility, and cultural norms, amongst others [Wendt, 1994].

\section{International Organization}

An international organization is an entity created and established by an agreement, pact, treaty, or concord bound by the instrument of government, international laws, and its legal personality. NATO is an example of an international political and military organization that aims at guaranteeing the freedom and security of its members and the world at large, through the implementation of both political and military means. International organizations are bound by international laws. These laws establish the standard of operations by international organizations as well as define their limitations as to that which is acceptable and that which is not in international relations. By this means, international organisations can have general reflections on how to adapt to a rapidly changing world [August, 2015].

\section{Statement of Problem}

The challenges are inherent in the state of affairs of NATO that an attempt to itemize each of them to fit into this section is equally a challenge. Top of the list as regards the composition of NATO is that it is still a reflection of the Post World War II. The organization was initially established as a means to create a counterweight to Soviet armies stationed in both Central and Eastern Europe after World War II. This problem can be identified in NATO's composition. At the moment, there are no representatives of member states of decolonized Africa. Also, there 
is the harsh reality of the relevance of NATO in today's global affairs. Is NATO relevant in today's pursuit of sustainable peacebuilding on a global scale? This reality stems from the changing character and profound complexity of peacebuilding itself [Gheciu, 2011].

This raises the question of effectiveness and legitimacy. The core of every organization is its domestic or international institutional legitimacy. This is how such organizations can thrive and transcend the barrier of time under conditions of complexities: when member states - as is the case with NATO - which experience actual or potential disparities can evolve with time the parameters of their functions, activities, and agenda under the scrutiny and approval of international law, the issue of institutional or organizational legitimacy is automatically resolved in itself [Dowling \& Pfeffer, 1975].

Lastly, beyond its member states, political analysts, researchers, diplomats, governmental institutions, and academics are to be well educated on the ever-evolving and progressive working methods of NATO. This creates flexibility and transparency in its operations.

\section{Theoretical Framework}

Regarding the discipline of international relations and the study of international organizations, no single theory is sufficient enough to adequately explain the importance of reconstructing NATO as well as exhaustively appraise the concepts and value posed by international organizations, with regards to its impact on a global scale. Thus, the theories most suitable for this paper are "Idealism" and "Realism".

Idealism is defined as an approach, in political science or international politics, that seeks the advancement of certain ideals, goals, and morality. Of such is the example of stability, world peace, or poverty reduction. Realism on the other hand deals with the study of reality and practice of international politics by emphasizing the role of nation-states and the position that all states are motivated by national interests, often disguised as moral and noble concerns. Realism and idealism are both terms that have been used in differing, sometimes opposite, senses in the history of philosophy while idealism seeks to establish the possibilities that are evident in an ideal society. Realism does not mean the platonic doctrine attributing reality to abstract ideas or the scientific concept attributing reality to actual situations, but rather the thought which takes into consideration the implications for the political life of those security and power factors which are inherent in human society [Wright, 1952].

Idealists believe to some degree that states have the tendencies to pursue their interests beyond the provisions of international law, but as rational actors, they would rather align and cooperate on the manifesto of international organizations. Beyond the great debate, idealism and realism shed light on the inherent contradictions in international relations that aim at establishing concrete and lasting solutions irrespective of the circumstances. For example, the United States and Russia stand at the top of the world, exactly equal in power, exactly equal in virtue, and each could fear with some justice that the other might steal a march on it, neither of them understanding for a moment or crediting the counter fear of the other [Thompson, 1977].

According to E.H. Carr, the problem and limitations of idealism in the interwar years was not international idealism but rather international idealism run amuck. He criticized the assumption that right-minded human beings could agree on other abstract normative principles to guide national behavior and that these principles, once understood and embodied in international law, would influence nations to act with greater justice [Goldsmith \& Krasner, 2003]. 
From a realist perspective, the discussion of international relations and international organisations encourages idealism about the constraining capacity of international law, as it may lead to prescriptions that will not work or that contradict the interests of powerful states that will hereby catalyze the collapse of legal institutions [Steinberg, 2002].

\section{The Reconstruction of NATO in the Post Trump Era}

To adequately assert the need for the reconstruction of NATO in the post Trump era, it is necessary to highlight the activities and policies of former president Trump and NATO as well as assess the overall impact on the organization and the world at large. "Even before his inauguration, President Donald J. Trump shook the foundations of NATO more than any of his predecessors."

Then-candidate Trump's statements about the unfair financial burden carried by the United States compared with its European allies were nothing fundamentally new in NATO's over seven decade history [Pothier \& Vershbow, 2017].

There arose the argument that NATO was "obsolete" because it was not doing enough to fight terrorism which caused puzzlement in European capitals given NATO's 15 years war against terrorism in Afghanistan [Pothies \& Vershbow, 2017]. President Trump further stated during his administration that "NATO is as bad as NAFTA. It's much too costly for the U.S."

The political rhetoric that came from President Trump has serious implications on NATO's integrity [Monov, 2019].

The foreign policy of the United States under former President Donald Trump was known for its unpredictability and reneging of prior international responsibilities and commitments. He espoused isolationist, protectionist, and non-interventionist views whilst projecting himself as a nationalist. The major thrust of his "America First" policy was the real reevaluation of prior multinational commitments of the United States, including its withdrawal from the transpacific partnership, the INF treaty, the UNHRC, UNESCO, and the Paris agreement, while urging NATO's allies to increase burden sharing. Donald Trump during his administration was the harshest critic of NATO ever to sit in the White House, first from his description of NATO as obsolete to threatening to leave the alliance [Benitez, 2019].

The American push to ensure "burden sharing", a key issue at the May 2017 mini-summit, came at a time of internal European distress. European members have since largely embraced the ideas projected to focus on the technical issues of the manner in which achieving the mandatory 2 percent of BNB is achievable [Tjalve, 2017].

As paying the bill was President Trump's absolute criterion for assessing the contribution of European countries, defense spending will remain a key NATO issue in the years to come. Those at the low levels of defense spending should be put under continuous pressure but it is less fair and even counterproductive to put the 'mediocre performers' in the same basket, for example, Germany, Trump's favorite country to be singled out as a poor performer. The German defense budget rose from some $€ 34$ billion in 2016 to over $€ 42$ billion as of 2020, which was then compared with the level of the UK's annual defense expenditure. A further rise to 1.5 percent of GAP by 2024, as announced by Chancellor Angela Merkel, implies a further rise in the German defense budget to approximately $€ 60$ billion [Zandee, 2018]. 
The United States is currently pivotal to the reconstruction of NATO, seeing most of the challenges faced by the organization as a result of the Trump policies which significantly altered its trajectory well over six decades before his election and inauguration as president of the United States. President Joe Biden's presence at the NATO Summit in Brussels on Monday (14th of June, 2021) is the first step towards the reconstruction of NATO. President Joe Biden expressed his strong commitment to the alliance and his support for the ambitious 2023 agenda. The Biden era has ushered some sort of renaissance in the sense of redesigning multilateralism. The change in the tone, message, and approach to trans-Atlantic relations is palpable, as President Biden has reaffirmed US commitment to the North Atlantic Treaty Organization [Ellehuus, 2021].

\section{RECOMMENDATION}

Member states' defense budgets are neither the roof of nor the challenges of NATO. The organization as a whole must address alliance survival in qualitative terms also as a contingency plan for the future, should any member choose to relinquish its pledged responsibility.

\section{Concluding Remarks}

There is no iota of doubt that the North Atlantic Treaty Organization needs to evolve and emerge if it is to be relevant in today's plan. NATO's potential capabilities are contingent on a unified Europe and this strong relationship with the United States. The issue of reconstruction is not merely administrative but systemic in order to avoid the tendencies of reaching a cul-desac, and until the reconstruction of NATO is adequately adopted and implemented, NATO risks being obsolete and subsequently dissolved.

\section{REFERENCES}

August Reinisch. (2015). General Reflections on International Organizations Adapting to a Rapidly Changing World. Proceedings of the Annual Meeting (American Society of International Law), 109, 283-286. doi:10.5305/procannmeetasil.109.2015.0283

Benitez, J. (2019). U.S. NATO Policy in the Age of Trump: Controversy and Consistency. The Fletcher Forum of World Affairs, 43(1), 179-200. Retrieved July 13, 2021, from http://www.jstor.org/stable/45289836

Benitez, J. (2019). U.S. NATO Policy in the Age of Trump: Controversy and Consistency. The Fletcher Forum of World Affairs, 43(1), 179-200. Retrieved July 11, 2021, from http://www.jstor.org/stable/45289836

Conley, R. (2020). Populist disrupter-in-chief. In Donald Trump and American Populism (pp. 1-57). Edinburgh: Edinburgh University Press. Retrieved July 11, 2021, from http://www.jstor.org/stable/10.3366/j.ctv1453j5t.4

Conley, R. (2020). The roots of Trump's populism. In Donald Trump and American Populism (pp. 158-202). Edinburgh: Edinburgh University Press. Retrieved July 12, 2021, from http://www.jstor.org/stable/10.3366/j.ctv1453j5t.6

Dowling, J., \& Pfeffer, J. (1975). Organizational Legitimacy: Social Values and Organizational Behavior. The Pacific Sociological Review, 18(1), 122-136. doi:10.2307/1388226 
Ellehuus, R. (2021). (Rep.). Center for Strategic and International Studies (CSIS). Retrieved July 14, 2021, from http://www.jstor.org/stable/resrep31143

Frydrych, E. (2008). The Debate on NATO Expansion. Connections,7(4), 1-42. Retrieved July 10, 2021, from http://www.jstor.org/stable/26323362

Gheciu, A., \& Paris, R. (2011). NATO and the Challenge of Sustainable Peacebuilding. Global Governance, 17(1), 75-79. Retrieved July 12, 2021, from http://www.jstor.org/stable/23033741

Goldsmith, J., \& Krasner, S. (2003). The Limits of Idealism. Daedalus,132(1), 47-63. Retrieved July 13, 2021, from http://www.jstor.org/stable/20027822

Goodman, E. (1953). The Soviet Union and World Government. The Journal of Politics, 15(2), 231-253. doi:10.2307/2126058

Hemmer, C., \& Katzenstein, P. (2002). Why Is There No NATO in Asia? Collective Identity, Regionalism, and the Origins of Multilateralism. International Organization, 56(3), 575607. Retrieved July 10, 2021, from http://www.jstor.org/stable/3078589

Kellner, D. (2018). Donald Trump as Authoritarian Populist: A Frommian Analysis. In Morelock J. (Ed.), Critical Theory and Authoritarian Populism (pp. 71-82). London: University of Westminster Press. doi:10.2307/j.ctv9hvtcf.8

Monov, L. (2019). NATO Under Pressure. Journal of Strategic Security,12(1), 1-14. Retrieved July 13, 2021, from https://www.jstor.org/stable/26623075

Nye, J. (1974). Collective Economic Security. International Affairs (Royal Institute of International Affairs 1944-), 50(4), 584-598. doi:10.2307/2615925

Panke, D., \& Petersohn, U. (2017). President Donald J. Trump: An agent of norm death? International Journal,72(4), 572-579. Retrieved July 11, 2021, from https://www.jstor.org/stable/26414137

Pothier, F., \& Vershbow, A. (2017). NATO and Trump: The Case for a New Transatlantic Bargain (pp. 1-4, Rep.). Atlantic Council. Retrieved July 13, 2021, from http://www.jstor.org/stable/resrep03492.3

Rappard, W. (1946). Collective Security. The Journal of Modern History, 18(3), 195-201. Retrieved July 12, 2021, from http://www.jstor.org/stable/1906205

Steinberg, R. (2002). Overview: Realism in International Law. Proceedings of the Annual Meeting (American Society of International Law), 96, 260-262. Retrieved July 13, 2021, from http://www.jstor.org/stable/25659784

Thompson, K. (1977). Idealism and Realism: Beyond the Great Debate. British Journal of International Studies, 3(2), 199-209. Retrieved July 13, 2021, from http://www.jstor.org/stable/20096802

Tjalve, V. (2017). (Rep.). Danish Institute for International Studies. Retrieved July 14, 2021, from http://www.jstor.org/stable/resrep13287

Wendt, A. (1994). Collective Identity Formation and the International State. The American Political Science Review,88(2), 384-396. doi:10.2307/2944711

Wimberly, C. (2018). Trump, Propaganda, and the Politics of Ressentiment. The Journal of Speculative Philosophy, 32(1), 179-199. doi:10.5325/jspecphil.32.1.0179

Windsor, P. (1975). The State of NATO. The World Today,31(8), 318-325. Retrieved July 10, 2021, from http://www.jstor.org/stable/40394869

Wright, Q. (1952). Realism and Idealism in International Politics. World Politics, 5(1), 116-128. doi: $10.2307 / 2009091$

Zandee, D. (2018). (Rep.). Clingendael Institute. Retrieved July 14, 2021, from http://www.jstor.org/stable/resrep21315 